\title{
O enredo e os personagens no processo de Jesus segundo Jo 18,1-19,37
}

\section{The plot and the Characters in the process of Jesus according Jn 18, 1-19,37}

\author{
Isidoro Mazzarolo
}

\section{Resumo}

A proposta deste artigo é um realce do itinerário da paixão, segundo a narrativa do evangelho de João. Ainda que o trabalho redacional do evangelho possa conter elementos teológicos concernentes aos tempos do redator, o Quarto Evangelho coloca os judeus como protagonistas no processo de crucifixão de Jesus. O evangelista conhece a prática da crucifixão no ambiente judaico, mesmo antes do domínio romano. O itinerário da paixão, segundo João, está mais nas mãos dos líderes religiosos de Jerusalém do que nas mãos dos romanos.

Palavras-chave: Enredo. Personagens. Processo. Crucifixão.

\section{Abstract}

The proposal of this article is a highlight of the itinerary of passion, according to the narrative of the Gospel of John. Although the redacional work of the Gospel may contain theological elements concerning the times of the writer, the fourth gospel places the Jews as protagonists in the process of crucifixion of Jesus. The Evangelist knows the practice of crucifixion in the Jewish environment, even before the Roman rule. The itinerary of passion, according to John, is more in the hands of the religious leaders of Jerusalem than in the hands of the Romans.

Keywords: Plot. Characters. Process. Crucifixion. 


\section{Introdução}

A literatura sobre o processo de Jesus é vastíssima e encontram-se desde estudos e textos pequenos de apenas algumas páginas, como será o nosso, até trabalhos que analisam o acontecimento sob os mais diferentes ângulos e ultrapassam mil páginas. Nós olharemos a narrativa joanina e os passos transcritos pelo evangelista. $O$ relato joanino não necessita ser tomado de modo literal ou histórico, mas também não podemos dizer que é somente teológico. Os relatos da paixão são uma combinação de história e da teologia querigmática. ${ }^{1}$

Dois aspectos precisam ser ressaltados nessa narrativa joanina:

a. as tentativas de Pilatos de libertar Jesus e o gesto de lavar as próprias mãos;

b. quem são os que conduzem Jesus do pretório até o Gólgota.

Todas as encenações da via-sacra cristã colocam, na caminhada da paixão e crucifixão, a presença de soldados romanos. Contudo, depois da entrega de Jesus aos líderes religiosos judaicos, com a declaração: eis o homem (Jo 19,4), essa tese não pode ser sustentada segundo a narrativa de João. A flagelação que Pilatos ordena aos soldados romanos, como forma de castigo e lição de moral para Jesus, tinha a finalidade de dissuadir os acusadores a fim de que desistissem do pedido de crucifixão. Pilatos experimenta o insucesso diante dos insistentes e intermitentes brados dos sumos sacerdotes e dos anciãos do povo - aron! aron! sttaurôson auton! Tira-o! Tira-o! Crucifica-o! - $(19,15)$. Pilatos, como pagão, fica estarrecido com esse urro e faz diferentes tentativas de persuasão desse intento. Ele manifesta interesse em libertar o Justo, mas tudo parece em vão e, então diz: crucificai-o vós mesmos!

Mesmo confundido com a postura de Jesus, Pilatos reconhece que a doutrina dele não significava qualquer ameaça a Roma e insiste na sua inocência. Diante da intenção de libertá-lo, os judeus utilizam seu último recurso: denunciar Pilatos a Roma como irresponsável e de favorecer os inimigos de César. ${ }^{2}$

Ainda que os evangelhos não sejam narrativas exclusivamente históricas, mas mais querigmáticas, não há como querer rejeitar a veracidade dos fatos.

\footnotetext{
${ }^{1}$ MAGGIONI, B., Os relatos evangélicos da Paixão, p. 116.

${ }^{2}$ VAWTER, B., Evangelio según san Juan, p. 514.
} 
Cabe-nos, portanto, buscar algo histórico naquilo que tem uma finalidade catequética. ${ }^{3}$ Nas últimas décadas surgiram muitas discussões sobre a responsabilidade última da morte de Jesus. Em Jo não está todo o processo de execução de Jesus, mas seguindo a sua trajetória, a responsabilidade passa das mãos dos romanos às mãos dos judeus. Como em todas as questões desta natureza, é fácil exagerar nas provas em ambos os sentidos e corre-se o risco de ser mal interpretado quando se busca dar aos textos um valor objetivo. ${ }^{4}$

\section{Jesus e o contexto greco-romano}

Os tempos de Jesus foram antecedidos por três séculos de convulsões, revoltas e frustrações da parte dos judeus, especialmente dos conservadores e radicais oriundos e partidários do puritanismo racial introduzido no pósexílio, ou mais precisamente, pela conhecida reforma de Esdras (Esd 9-10).

A legislação grega de Sólon (638 a.C. - 558 a.C.) inseriu algumas reformas de cunho sociopolítico na Grécia com o objetivo de tornar a sociedade mais participativa e responsável de toda a vida na pólis. Na mesma época, os romanos criavam o sistema republicano. Os sistemas jurídicos grecoromanos já estavam bastante estruturados e seus princípios eram baseados em questões civis. As questões religiosas não faziam parte desses códigos jurídicos. A religião era uma escolha pessoal e os mitos, crenças e ritos não dependiam de leis superiores. Os códigos de leis civis romanas protegiam os cidadãos romanos contra as possíveis arbitrariedades dos códigos particulares das Cidades-Estado. É o que vemos nas diferentes tentativas de incriminação de Paulo por parte dos judeus diante das falsas acusações ao procurador de Corinto, Galião (At 18,12-17), diante do processo e acusações dos judeus em Jerusalém (At 22,22-29) e, finalmente, em Roma. É nessa perspectiva que propõe-se a leitura da paixão segundo o evangelho de João. Jesus não possuía cidadania romana e Pilatos não pôde aplicar a Jesus as mesmas regras que o tribuno de Jerusalém utilizou para tirar Paulo das mãos dos judeus de Jerusalém e enviá-lo a Festo, em Cesareia Marítima (At 23,12-35). Veremos como Pilatos tenta dissuadir os acusadores da condenação de Jesus; mas ele só tinha argumentos éticos e não jurídicos.

\footnotetext{
${ }^{3}$ SWEET, J. P. M., The Zealots and Jesus, p. 3.

${ }^{4}$ VAWTER, B., Evangelio según san Juan, p. 516.
} 


\section{Jesus e os grupos judaicos}

\subsection{Jesus e os zêlôtês}

O nome zêlôtês indica o movimento conhecido como os zelosos por Deus. ${ }^{5}$ Esse movimento se caracterizava como zeloso, cuidadoso e rigoroso com os costumes e práticas da vida quotidiana e religiosa ${ }^{6}$ Esse lexema projeta o sentido social até nossos dias: zelador, zelar, cuidar ou preservar. Mas, esse sentido religioso tomou uma conotação política e cultural. As circunstâncias e os percalços do povo da Palestina, diante dos seus conquistadores-opressores, transformaram o conceito de zeloso por lutador, guerreiro. Os zelotes alimentavam uma filosofia de libertação. Eles eram um movimento bélico e tinham transformado o Templo em um covil de ladrões (Jr 7,11; Lc 19,46).

As teorias de que Jesus ou parte do seu movimento estava misturado com os zelotes na luta armada contra Roma jamais ficaram comprovadas. ${ }^{7}$ Jesus deve ter sido um judeu zeloso pelo seu povo, pela sua pátria, mas não agarrado à terra e ao nacionalismo racial tal qual era sustentado e defendido pelos zelotes. Jesus tinha um olhar mais abrangente do que o simples nacionalismo político; ele não concordava com muitas coisas das tradições (Mt 5-7) e condenava a violência, a falsidade religiosa e a corrupção ao redor do Templo (Mc 11,15-19 e par.). É sob esse olhar que o zelotismo indicava a combinação de dois termos: zêlós e lêstês. Nos evangelhos de João e de Marcos, o lexema zêlós (zeloso) assume o sentido do antirreino, por isso a configuração de lêstês (ladrão). ${ }^{8}$

Jesus podia discordar dos impostos que Israel pagava para Roma, mas tinha clareza de que aquilo que deveria ser tributado a Deus não poderia ser dado a César e vice-versa (Mc 12,13-17). Nesse caso, ele não discordava apenas da opressão de Roma, mas muito mais do comportamento das lideranças religiosas e políticas de Jerusalém às quais chamou de hipócritas (Mt 23,1-39).

\footnotetext{
${ }^{5}$ STUMPFF, A., Zêlos, zêlôtês, p. 884.

${ }^{6}$ HENGEL, M., The Zelots, p. 146-223. O estudo de Hengel sobre o movimento dos zelotas é muito abrangente, mas ele dá um destaque a Judas, o Galileu, nos tempos das Guerras Judaicas.

${ }^{7}$ SWEET, J. P. M., The Zealots and Jesus, p. 1.

${ }^{8}$ BAMMEL, E., The poor and the Zealots, p. 125.
} 
Alguns exegetas acreditam que o zelotismo era uma filosofia de libertação, mas sempre com o perfil bélico. Conforme Boring, eles eram um movimento de bandidos e ladrões. ${ }^{9}$

Se os cristãos fossem simpatizantes dos zelotes, teriam pegado em armas e lutado com eles, mas a pedagogia cristã segue por outro caminho. A resistência pacífica dos cristãos não pode ser misturada com as lutas armadas de libertação dos movimentos "messiânicos" judaicos, desde a resistência dos macabeus ao movimento expansionista de Antíoco Epífanes (185 a. C. aprox.) até a última intifada de Bar Kockba, em 136 d. C., o qual protagonizou a segunda revolta contra os romanos e se transformou em um herói legendário. ${ }^{10}$ Josefo vincula o movimento belicoso dos zelotas com a filosofia da família dos Herodes quando Herodes, o Grande, como idumeu, fez guerras para a conquista do poder. ${ }^{11}$

\subsection{Jesus e os essênios}

Os essênios eram conhecidos como uma parcela dos judeus pios, conservadores e escrupulosos referente aos ritos, à lei e à justiça. Um dos seus líderes chamado Manahem era muito estimado por Herodes por ser estudioso e saudava-o sempre com o título de rei. A característica principal era a piedade devotada a Deus. ${ }^{12}$ Ainda que fossem considerados dissidentes do "centrão" que gerenciava o templo e as corporações corrompidas de Jerusalém, eles não podem ser tratados como rebeldes, mas como incorformistas com a corrupção. Essa seria uma das teorias da formação dos essênios. A outra seria a chegada de judeus conservadores da Babilônia, no final do IV século, e não teriam concordado com os resultados da reforma de Esdras (Esd 9-10). ${ }^{13}$

João Batista segue esse caminho de rejeição à corrupção e ao despotismo hipócrita da cidade e, abdicando das suas condições de sacerdote pelas de um profeta ambulante vivendo uma vida inóspita no deserto. Jesus também vai ao deserto de Jericó conhecer esse tipo de vida daqueles que viviam uma expectativa messiânica.

O fato de Jesus ter-se feito batizar por João Batista, no Jordão, nas

${ }^{9}$ BORING, M. E., Introdução ao Novo Testamento, p. 163.

${ }^{10}$ YADIN, Y., Bar-kokhba, p. 18.

${ }^{11}$ JOSEPHUS, The New Complete Works of Josephus, 4.3.9.

12 JOSEPHUS, The New Complete Works of Josephus, 15.10.5.

${ }^{13}$ MAZZAROLO, I., João Batista e Jesus conheceram os essênios?, p. 120. 
proximidades de Jericó, pode ser um indício de que Jesus e João tinham bom conhecimento e até relacionamento com os essênios. Alguns aspectos da vida dos essênios exigiram de João e de Jesus a ruptura: 1. a autoeleição como filhos da luz, donos absolutos da verdade; 2. a era messiânica a ser instaurada pela guerra dos filhos da luz contra os filhos das trevas; 3. a separação e a não comunhão com os de fora da seita.

Os essênios se retiraram do Templo de Jerusalém por considerá-lo um lugar de mentiras, insultos e violências, práticas incompatíveis com a sua finalidade. Os essênios criaram sua própria casta de sacerdotes e, no deserto, estavam voltados para o novo templo em Damasco. ${ }^{14}$

Jesus também manifesta sua indignação contra o Templo e ele vai ao deserto onde João batizava e se faz batizar por ele, mas queria devolver ao Templo a sua dignidade de lugar de oração para todos os povos (Is 56,7). A entrada triunfal em Jerusalém acompanhado pelas multidões e a expulsão dos cambistas e negociantes dos arredores do Templo demonstra o movimento contrário ao dos essênios (Mt 21,1-17 e par.). Jesus toma posse da sua cidade e, com a unção do Espírito do Senhor (Lc 4,18-19; Is 61,1-2), instaura a verdadeira era messiânica e o verdadeiro messianismo do Reinado de Deus (Is 11,1-5).

\subsection{Jesus e os fariseus}

É o movimento ou partido religioso dos fariseus que mais tem incidências na missão de Jesus e no cristianismo primitivo. Os fariseus eram conservadores e consideravam-se os fiscais da fé. Eles estavam presentes em quase todas as cidades importantes do Império Romano. Opunham-se de modo radical às posturas de Jesus (Mt 23,1-36) e faziam oposição às propostas do evangelho (Jo 8,36-48; 11,45-54). Esse movimento de opositores a Jesus é mencionado 90 vezes nos evangelhos ( $29 \mathrm{em} \mathrm{Mt,} 26 \mathrm{em} \mathrm{Lc}, 19$ em Jo e 11 em Mc).

\subsection{Jesus e os movimentos messiânicos judaicos}

As expectativas messiânicas judaicas sempre se caracterizaram por esperanças de supremacia política, econômica e um anseio de hegemonia militar. Muitos candidatos a messias conseguiram organizar grupos de pessoas

\footnotetext{
${ }^{14}$ PAGANINI, S., Gesù, Qumran e gli esseni, p. 38.
} 
conscientes da sua dignidade, dos seus direitos e do sofrimento injusto imposto pelos opressores.

A afirmação de Jesus pode soar como acusação apologética, mas não passa de uma constatação histórica: "Todos os que vieram antes de mim são ladrões e assaltantes" (Jo 10,8). Alargando o olhar sobre os movimentos messiânicos judaicos desde os tempos de Antíoco Epífanes (185 a.C. aprox.) em diante, pois até o último deles, Bar Kockba (136 d. C.), todos eles foram movimentos violentos, de lutas armadas e derramamento de muito sangue.

Os ciclos messiânicos sempre tiveram lugar nas mais diferentes religiões; mais abundantes, no entanto, no judaísmo do que nas outras como o xintoísmo, o taoísmo e o confucionismo. ${ }^{15}$ Nessa mesma ótica, caminha Guevara (1985) ao analisar o ambiente político nos tempos de Jesus. ${ }^{16}$

\section{Contexto do evangelho segundo João}

O relato joanino, no seu estado atual, apresenta algumas dificuldades e a sua elaboração teria conhecido três fases sucessivas. ${ }^{17}$ A primeira fase poderia ser a do ambiente do apóstolo João que compreende os sinais; a segunda seria a composição dos monólogos ou discursos; a terceira seria a reelaboração dos discursos e da paixão pelo mesmo redator da segunda fase.

As diferentes redações se passariam sempre dentro de mesma escola joanina. O início é muito influenciado pelo pensamento samaritano, mas a segunda fase espelha melhor o ambiente da Ásia Menor ou, mais precisamente, de Éfeso, com a nova problemática da hostilidade no meio judeu-cristão. ${ }^{18}$

O ambiente, especialmente na segunda fase, está envolvido numa tensão com as estruturas do templo. A destruição de Jerusalém, no ano de setenta, provocou um conflito mais acirrado nas relações entre cristãos e judeus. Sem

\footnotetext{
${ }^{15}$ DESROCHE, H., Dicionário de Messianismos e Milenarismos. O autor faz uma pesquisa sobre uma quantidade enorme de personagens que decidiram encampar movimentos messiânicos ou milenaristas. Todos eles, no entanto, foram movimentos violentos, de manipulação de pessoas e de desgraças sociais.

${ }^{16}$ GUEVARA, H., Ambiente Político del Pueblo Judio en Tiempos de Jesus. Essa obra estuda os relatos de dois judeus dessa época: Flávio Josefo e Filon de Alexandria. Em ambos os autores, com apoio de outros testemunhos contemporâneos, Guevara mostra como as articulações e movimentos na Palestina, encampados pelos bandoleiros, sicários e zelotes, organizavam guerrilhas, insurreições e motins contra os romanos.
}

${ }^{17}$ BOISMARD, M-É.; LAMOUILLE, A., L’Évangile de Jean, p. 9.

${ }^{18}$ BOISMARD, M-É.; LAMOUILLE, A., L’Évangile de Jean, p. 11. 
o templo, as tradições, alguns valores dos antepassados e outros elementos culturais e religiosos judaicos se perderam e outros passaram para a sinagoga.

O relato joanino apresenta Jesus em conflito com os judeus $(1,19 ; 2,13-$ $22 ; 5,16-18)$ e, gradualmente, o conflito se estende a todo aquele que confessa que Jesus é o Cristo $(9,22 ; 12,42 ; 16,2) .{ }^{19}$ De forma análoga, é a luta deles contra Pilatos, quando percebem o desejo dele de libertar Jesus da execução $(18,28-19,26)$.

\subsection{O prólogo de João}

O relato joanino não é uma narrativa ou uma cronologia instantânea elaborada no momento dos fatos, mas uma retomada dos fatos da tradição, fatos estes iluminados pelo contexto da época da redação. No prólogo, o narrador afirma que Jesus veio como a Luz e a Vida dos homens e, a Luz brilhou nas trevas, mas as trevas não a quiseram acolher (Jo 1,4-5). As trevas representam o submundo do pecado e da resistência ao novo nascimento, ao nascimento do alto e à permanência no mal (Jo 3,19-21).

E, de modo mais enfático, João declara que Ele veio para o que era seu, mas os seus não o receberam (Jo 1,11). Nesse particular, João coloca um detalhe estilístico bastante forte e claro: Ele veio para o que era seu (idia = neutro plural), mas os seus (idioi = masculino plural). Tudo era seu, mas os seus não o acolheram. Encontramos aqui um substrato da parábola dos vinhateiros homicidas (Mt 21,33-46). Depois de enviar diversos empregados à vinha para solicitar a prestação de contas, ele enviou seu filho amado e único, mas os vinhateiros trataram-no do mesmo modo que os servos do pai. Talvez seja sob essa ótica que se coloca o redator joanino para narrar o contexto de Jesus com as autoridades religiosas e chefes do povo: "odiaram-me sem motivos" (Jo 15,25; S1 35,19; 69,5).

\subsection{Jesus e o relacionamento com os chefes dos judeus}

Os conflitos de Jesus com as autoridades e chefes do povo são constantes (Jo $5,16.18 ; 7,1.19 ; 8,59 ; 10,31.39 ; 15,25)$. Depois da cura do paralítico na piscina de Betesda, em dia de sábado (Jo 5,9) os judeus iniciam seu processo acusatório e já querem fazê-lo morrer por violar o sábado $(5,18)$; após o

\footnotetext{
${ }^{19}$ MOLONEY, F., The Gospel of John, p. 9.
} 
discurso onde ele (Jesus) afirmou ser o "pão descido do céu" $(6,41)$ nos judeus aumenta o desejo de eliminá-lo do meio do povo $(7,1)$; na discussão sobre a própria genealogia, Jesus afirma que ele é o filho de Abraão, mas os judeus não são filhos de Abraão porque querem mata-lo $(8,40)$ e, logo tomam pedras para atirar nele $(8,59)$; da mesma forma na festa de Dedicação, em Jerusalém, eles apanham pedras para jogar nele $(10,31)$.

O complô contra Lázaro pode indicar também a perseguição das autoridades dos judeus aos cristãos, especialmente depois de Jamnia. Esse poderia ser o ambiente dos tempos do evangelista e ele transfere os conflitos de seu tempo para os tempos de Jesus. Assim, as autoridades não perseguem apenas Jesus, mas também os efeitos de sua obra. ${ }^{20}$

Nos evangelhos sinóticos, que devem ser considerados também como textos entre a história e a mensagem, pois entre os fatos e os textos está a comunidade ${ }^{21}$ que lê e interpreta o seu passado, encontramos diversos episódios de conflito com os judeus e a culpabilidade dos anciãos e chefes religiosos. No início da obra marcana, emerge uma acusação tão forte contra Jesus que o separa de seus familiares: os escribas, que tinham descido de Jerusalém para a Galileia, diziam que ele estava possesso pelo pior dos demônios, que eles chamavam Beelzebul (Mc 3,22-35).

\subsection{As tensões entre a pedagogia de Jesus e as autoridades dos judeus}

As ameaças dos judeus a Jesus eram uma constante (Jo 5,18; 7,1.19.25.30; $8,59 ; 10,31.39 ; 11,53 ; 12,10 ; 15,25 ; 17,18)$. Jesus caminhava na contramão das tradições judaicas. Suas palavras, ensinamentos e sinais conduziam sua vida e a de seus seguidores com autonomia, com liberdade e com a unção do Espírito do Senhor (Lc 4,18-19) para implantar o Reino de Deus, mas tudo isso afrontava as tradições e costumes fechados dos sacerdotes e chefes do povo.

É diante desse quadro de tensões que Jesus começa encarar a possibilidade da paixão. Ainda que, segundo alguns autores, as narrativas dos anúncios da paixão estejam voltadas para a certeza da ressurreição, ${ }^{22}$ são as ameaças constantes de perseguição e morte que exigem de Jesus uma preparação sólida para o que adviria.

\footnotetext{
${ }^{20}$ MAZZAROLO, I., Nem aqui, nem em Jerusalém, p. 212.

${ }^{21}$ MORGAN, D. F., Between Text \& Community, p. 16.

${ }^{22}$ BASTIN, M., Jésus devant sa passion, p. 124.
} 


\section{O enredo e os personagens no processo de Jesus}

Os estudos recentes cada vez mais evidenciam as formas arbitrárias no processo e na responsabilidade das autoridades de Jerusalém na condução dos últimos eventos da vida de Jesus. Marcos apresenta a semana da paixão de um modo mais ordenado onde tudo acontece em uma semana, desde a entrada triunfal em Jerusalém e sua crucifixão. ${ }^{23}$ A narrativa de Marcos pode ser compreendida a partir dos objetivos do evangelista que era escrever um relato breve para leitores já integrados no evangelho.

Muitos exegetas se debruçam sobre a historicidade dos fatos ou sobre a interpretação dos evangelistas como relatos correspondentes ao tempo dos redatores neotestamentários. ${ }^{24}$

A narrativa joanina, ainda que historicamente considerada a mais tardia, não está longe daqueles que acompanharam os fatos. João compõe com estilo um pouco diferente dos outros evangelhos, narra o discurso de despedida de Jesus, considerado o seu testamento aos discípulos (Jo 17,1-26 - para alguns autores o discurso de despedida abrange os capítulos 14-17). Depois, Jesus se dirige ao Cedron e lá havia um jardim. $\mathrm{O}$ termo Cedron é indicado apenas por João. Marcos e Mateus falam do Monte das Oliveiras (Mc 14,32; Mt 26,36) e Lucas fala do Getsêmani (Lc 22,39).

\section{Primeiro ato:}

a. Jesus estava no vale do Cedron, onde havia um jardim, e, frequentemente, dirigia-se a esse lugar para rezar, com os seus discípulos $(18,1-2) ;{ }^{25}$

b. Judas conhecia bem o ambiente. Jesus se reunia amiúde (pollákis) no local com seus discípulos. Judas, depois do pacto, tomou consigo a coorte ${ }^{26}$ dos sumos sacerdotes e guardas dos fariseus, ${ }^{27}$ levando tochas e armas $(18,3)$;

\footnotetext{
${ }^{23}$ SCHONFIELD, H., The Passover Plot, p. 127.

${ }^{24}$ COUSIN, H., O profeta assassinado, p. 21.

${ }^{25}$ Lucas 22,39 diz que era costume ("ethos") de Jesus ir ao monte orar. O texto joanino fala frequentemente, utilizando o vocábulo grego pollákis $(18,2)$.

${ }^{26}$ BAUER, W., speira, p. 1507, no grego é traduzida para o latim por "coorte", que corresponderia à décima parte de uma legião.

${ }^{27}$ MOLONEY, F. J., The Gospel of John, p. 488. Esses hypêretai eram os seguranças dos sumos sacerdotes e dos chefes do povo. BOISMARD, M.-É.; LAMMOUILLE, A., L'Évangile de Jean, p. 407, afirma que a expressão guardas dos judeus não é retórica, mas é atestada no Documento C, fonte primária do IV evangelho e Judas vai ao Getsêmani com esses guardas enviados pelos sumos sacerdotes $(18,3)$. Portanto, é a esses guardas que Pilatos entrega Jesus quando diz:
} 
c. Simão Pedro tenta uma reação precipitada, mas Jesus o repreende e concerta o erro $(18,10)$;

d. Os guardas dos judeus ataram Jesus e o conduziram a Anás, sogro de Caifás, ${ }^{28}$ que era o sumo sacerdote naquele ano $(18,12-13)$. O sumo sacerdote interrogou Jesus a respeito de seus discípulos e de sua doutrina $(18,19)$, mas não houve um processo formal por ser durante a noite. O processo só poderia ser feito de dia. ${ }^{29}$ Para Champlin o processo foi ilegal. A punição não podia ser decretada à noite e Jesus foi sentenciado a morrer durante a noite. Se, porventura, sentenciaram Jesus pela manhã e o crucificaram no mesmo dia, também era um ato ilegal, pois a morte não poderia ocorrer no mesmo dia da sentença. ${ }^{30}$

Segundo ato: Jesus diante dos sumos sacerdotes e o inquérito religioso

a. Anás havia dado um conselho aos anciãos de que era melhor que um só perecesse do que todo o povo pudesse sofrer $(11,50 ; 18,14)$;

b. O sumo sacerdote faz o interrogatório a Jesus a respeito da sua doutrina $(18,19-23)$;

c. Pedro, tomado pelo medo, nega Jesus, primeiro diante de uma criada que guardava a porta e depois diante dos servos do sumo sacerdote $(18.17-27) ;{ }^{31}$

d. De Anás a Caifás (o sumo sacerdote titular) - Jesus é sempre levado manietado como se fosse um prisioneiro perigoso $(18,24)$;

e. De Caifás ao pretório de Pilatos, no alvorecer $(18,28)$. Era preciso fazer tudo muito rápido, antes que o povo tomasse consciência do que estava acontecendo. Os evangelhos de Mc 14,11 e Lc 22,6 salientam que os chefes do povo procuravam o momento oportuno (eukairôs) para manter o povo na ilusão. Quem tem medo de Jesus são os líderes

Eis o vosso rei $(19,14)$ e não aos soldados romanos.

${ }^{28}$ LÉON-DUFOUR, X., Leitura do Evangelho segundo João, p. 55, afirma que Caifás mantinha boas relações com Pilatos, citando P. Lémonon, Pilate et le gouvernement de la Judée, Paris: Gabalda, 1981, p. 202 e S. Legasse. I, 75-77.

${ }^{29}$ VAWTER, B., Evangelio según san Juan, p. 508.

${ }^{30}$ CHAMPLIN, R. N., Lucas; João, p.600.

${ }^{31}$ BOISMARD, M.-É.; LAMOUILLE, A., L’Évangile de Jéan, p. 411, afirma que as negações de Pedro não seriam mais que uma, mas a narrativa depende de uma reelaboração de Lucas sobre o Protomarcos. 
religiosos e não Pilatos. Os que conduzem Jesus a Pilatos já chegam como uma sentença pronta: "se não fosse um malfeitor, não o teríamos conduzido a ti" $(18,30)$.

f. Jesus diante de Pilatos e o interrogatório de um pagão: o resultado é a convicção da inocência do acusado (18,29-38).

Terceiro ato: Jesus e Pilatos

a. Ao receber a comitiva, Pilatos pergunta aos acusadores: "Que acusação trazeis contra este homem?" Os sumos sacerdotes e os chefes do sinédrio respondem que Jesus era um malfeitor $(18,30)$;

b. Pilatos não acredita na acusação e no pedido de morte arguido pelos chefes do povo e líderes religiosos. Se Jesus fosse um revolucionário belicoso, Pilatos estaria informado. Jesus, contudo, não se enquadrava no regime de dolo pelo Direito Romano, por isso pede que eles o julguem segundo as leis deles $(18,31)$

c. Resposta dos acusadores: Não nos é permitido condenar ninguém à morte (essa argumentação é falaciosa, pois, mesmo que os romanos tivessem tirado o poder de vida ou morte do Sinédrio, eles conseguiam sempre aplicar o próprio código de matar por apedrejamento, estrangulamento ou crucifixão - Lv 20,8-27);

d. Pilatos conversa com o acusado e não pergunta sobre crimes ou motivos de dolo, mas se ele era de fato rei $^{32}$ dos judeus $(18,13) ;{ }^{33}$

e. Pilatos esclarece que Jesus tinha sido entregue pelos chefes dos sacerdotes e do povo e pergunta novamente se Jesus era de fato rei? Ele responde que veio para dar testemunho da verdade e que o seu reino não é deste mundo (18,35-37).

Quarto ato: Pilatos apresenta Jesus às turbas e aos sumos sacerdotes

a. Mesmo não tendo presenciado o diálogo com Jesus, os judeus sabiam que Pilatos estava disposto a libertá-1o, ${ }^{34}$

\footnotetext{
${ }^{32}$ LÉON-DUFOUR, X., Leitura do Evangelho segundo João, p. 53. O autor afirma que a redação joanina retém a responsabilidade dos judeus e a contemplação de Jesus rei. É como o rei cujo reinado não é deste mundo que ele se apresenta como testemunha da verdade.

${ }^{33}$ A realeza de Jesus não comprometia a autoridade romana, mas os interesses dos seus, especialmente o poder corrompido do Templo.

${ }^{34}$ LÉON-DUFOUR, X., Leitura do Evangelho segundo João, p. 77.
} 
b. Pilatos faz a declaração pública da inocência de Jesus, mas os judeus não aceitam;

c. Uma solução poderia amenizar a fúria da multidão: condenar um bandido chamado Barrabás, ${ }^{35}$ e soltar o inocente $(18,39)$;

d. A decepção de Pilatos: a multidão, sublevada pelos seus chefes, clama pela liberdade do criminoso e pela condenação do inocente $(18,40)$.

Quinto ato: Pilatos faz uma última tentativa de libertação

a. Ordena a flagelação de Jesus. Essa era uma prática romana para castigar e depois libertar acusados ou suspeitos de atos contra a lei $(19,1)$. A flagelação era a pena imposta antes da soltura, por isso, depois de ter ordenado a flagelação, na compreensão de Pilatos, Jesus deveria ganhar a liberdade;

b. Os soldados romanos, depois de torturá-lo, colocaram uma coroa $^{36} \mathrm{de}$ espinhos em sinal de ironia e de sarcasmo à figura do rei e um manto de púrpura; ${ }^{37}$

c. Pilatos torna a apresentar-se diante das turbas, com o criminoso (Jesus) punido e devidamente castigado, esperando ter agradado aos seus inimigos e poder libertá-lo (19,2-5).

Sexto ato: Pilatos diante do paradoxo ${ }^{38}$

Diante das autoridades, Pilatos reapresenta Jesus dizendo: Eis o homem, devidamente punido e castigado $(19,5)$ ! Com essa apresentação do homem totalmente desfigurado, ele acreditava estar pondo a salvo o inocente, ${ }^{39}$

\footnotetext{
${ }^{35}$ A proposta de solução com a troca de Jesus por Barrabás foi uma iniciativa de Pilatos que não aceitava a condenação do inocente.

${ }^{36}$ A coroa de louros era dada aos heróis nas competições esportivas ou nas batalhas. Era uma condecoração pela bravura e êxito. A coroa de espinhos significava um instrumento de tortura e ironia. Pode ser uma forma de desprezo proposital com o "rei dos judeus", e, por isso, espinhos em lugar de louros.

${ }^{37}$ A púrpura era um tecido nobre e referencial aos poderosos. O Ap 17,4 e 18,16 associa o manto de púrpura com a cor imperial. Essa seria outra investida irônica ao "rei".

${ }^{38}$ FERRARO, G., L'ora di Cristo nel Quarto Vangelo, p. 119, distribui as cenas de Jo 18,28 a 19,16 em sete fases ou cenas de Jesus diante de Pilatos e das autoridades dos judeus.

${ }^{39}$ A apresentação de Jesus aos sumos sacerdotes, fariseus e ao povo, após a flagelação, é um passo anterior e diferente do momento da entrega aos judeus com a expressão: Eis o vosso rei $(19,14)$. Eis o homem significa: vede-o castigado, pagou o seu pecado, podemos soltá-lo!
} 
a. A multidão exclama em uníssono: Crucifica-o! Crucifica-o $(19,6)$ !

b. Pilatos insiste: Não encontro motivo de condenação $(19,6)$;

c. A multidão, manipulada pelos chefes, exclamava: Nós temos uma lei e, segundo essa lei, ele deve morrer porque se fez Filho de Deus (19,7; Lv 24,16);

d. Pilatos quer mostrar seu poder de condenação ou libertação, mas Jesus fala que o poder emana de Deus e, quem o entregou a ele tem mais pecado $(19,11)$;

e. Diante da insistência de Pilatos em libertar Jesus, os judeus ameaçam acusá-lo diante de César $(19,12)$;

f. Decisão final: Pilatos lava as mãos e entrega Jesus aos judeus, dizendo: Eis o vosso rei! E eles o conduzem para fora da cidade para crucificá-lo (19,16-18);

g. O letreiro de Pilatos: Jesus Nazareno Rei dos Judeus $(19,19)$ !

Conforme as narrativas evangélicas da paixão, Pilatos utilizou todos os mecanismos possíveis para libertar Jesus e, mesmo reconhecendo sua absoluta inocência, interrogou e castigou Jesus, segundo os costumes romanos, a fim de tentar dissuadir os judeus de seus intentos, mas tudo fracassou. Então, ele entregou a vítima aos seus algozes e eles o crucificaram. A condução final do processo condenatório e execratório de Jesus coube às autoridades judaicas e não aos romanos. ${ }^{40} \mathrm{~A}$ presença das forças de segurança romanas, como no caso de Mc 15,39, referindo à presença do centurião romano, revela a possível determinação de Pilatos para que os soldados romanos evitassem um confronto entre os algozes dos sumos sacerdotes e os discípulos de Jesus. A fúria dos anciãos e religiosos de Jerusalém podia encontrar os adeptos e simpatizantes de Jesus e gerar um conflito sangrento, por isso Pilatos deve ter destacado uma guarnição de soldados, comandados por um centurião, a fim de deixar que os seguranças dos sumos sacerdotes executassem o seu projeto.

Enquanto com a expressão: Eis o vosso rei, Pilatos está entregando a vítima solicitada e também a responsabilidade sobre o seu destino.

${ }^{40}$ As encenações da paixão de Jesus, nos rituais cristãos da sexta-feira da paixão não deveriam apresentar soldados romanos, mas os capangas dos sumos sacerdotes e autoridades do templo, pois foram eles que se dirigiram ao Getsêmani para prender Jesus, liderados por Judas (18,2-3). 


\subsection{A traição de Judas e o processo religioso}

Os conflitos narrados pelos escritos do NT revelam uma indisposição entre Jesus e as autoridades de Jerusalém. As ameaças e perseguições sempre foram movidas por problemas de diferenças na interpretação da lei e das tradições e a nova hermenêutica ensinada por Jesus a seus discípulos: curar doentes (Mc 1,23-27), tocar em defuntos (Lc 7,11-17), esfolar espigas (Lc 6,1-5), ter contatos com mulheres de conduta duvidosa (Lc 7,36-50), perdoar pecados (Jo 8,1-11) e, de modo discursivo-catequético, o Sermão da Montanha (Mt 5-7).

A nova hermenêutica ética e religiosa foi a causa principal do início dos conflitos. O judaísmo é fruto do seu tempo e cultura, por isso se caracterizou como uma sociedade fechada e não aceitava mudanças nos seus esquemas sacralizados no pós-exílio. Herodes, que governava com força e maldade, era hostilizado por favorecer hábitos helenísticos em Israel. Depois de sua morte houve uma grande rebelião contra os seus filhos. ${ }^{41}$

Judas foi definido pelo evangelista como ladrão no momento em que reclamou do desperdício do perfume, quando Maria ungiu os pés de Jesus $(12,6)$. A ganância fez Judas vender sua alma por dinheiro. Ele não fez qualquer confabulação com Pilatos ou autoridades romanas, mas com os sumos sacerdotes e chefes do povo. O valor da entrega e da traição foi de trinta moedas de prata (Mt 27,3). Não temos nenhuma indicação, quer pelos textos canônicos, quer pelos textos apócrifos, que Roma perseguisse os cristãos nessa época.

O dinheiro pela traição não veio dos romanos, mas das autoridades de Jerusalém. As tentativas repetidas de eliminá-lo estavam sempre a cargo dos chefes religiosos. O processo de Jesus não tem fundamentação jurídica, isto é, criminal, mas religiosa, de ciúmes, invejas e ódio das instituições judaicas (Jo 15,25).

A prisão de Jesus, no Getsêmani, foi orquestrada na calada da noite pelos sumos sacerdotes e anciãos do povo, liderada pelo traidor Judas, levando consigo tochas e uma gangue de gângsteres (Jo 18,3). Ela foi realizada na escuridão, indicando o esquema obscuro e macabro na articulação do plano funesto contra o justo. A articulação das obras da noite indica que elas são más (Jo 3,19).

${ }^{41}$ GUEVARA, H., Ambiente Político del Pueblo Judio en Tiempos de Jesus, p. 144. 
Analisando os textos de Jo 18,31 e 19,6-7, Blinzler afirma que os textos revelam uma contradição na própria argumentação dos acusadores. ${ }^{42}$ A afirmativa de que eles não poderiam condenar ninguém não é verdadeira, pois o sinédrio tinha poderes para condenar pessoas comuns à prisão ou até à sentença capital. Normalmente esses casos eram decididos na base de algumas testemunhas, mesmo que fossem falsas e as sentenças pronunciadas sem a necessidade de instauração de um processo propriamente dito. Por isso, quando Pilatos lhes diz: idou ho antrôpos (eis o homem, Jo 19,5), eles, imediatamente, o tomam e afirmam: Nós temos uma lei, e segundo essa lei, ele deve morrer porque fez a si mesmo filho de Deus (Jo 19,7). As decisões do Sinédrio poderiam ser conduzidas pelo ódio ou ciúme, sem que houvesse muito tempo para a razão e a reflexão. No processo de Jesus, o que encontramos nos relatos é um grito uníssono, orquestrado pelas autoridades, chefes do povo e lideranças religiosas e, diante do eco das vozes, não havia espaço para o raciocínio de Pilatos.

\subsection{Pilatos e o Direito Romano: o processo civil}

"Mesmo sem ter acompanhado o diálogo, os judeus sabem que Pilatos está disposto a soltar Jesus" ${ }^{43} \mathrm{O}$ ponto de partida é o sistema religioso e político dos romanos. Antes de conquistarem a Grécia, por volta do IV século a.C., os romanos buscavam na cultura e nos filósofos helenísticos bases para a construção de seu código de Direito Civil. Os gregos, além de desenvolverem a filosofia e as discussões sobre a vida na pólis, também sustentavam a importância da liberdade religiosa.

Pilatos não pôde utilizar o Código Civil Romano para defender Jesus por que ele não era cidadão romano; no entanto, usou dos princípios de liberdade religiosa que a legislação romana outorgava a todos os cidadãos. No processo de Jesus não se aplicam questões pagãs de idolatria ou culto aos reis de Roma, mas de ofensas aos princípios judaicos (Lv 24,26; Jo 19,7): Ele se fez filho de Deus! Segundo a lei de Roma, ele é inocente! Esse é o conflito de Pilatos. Ele jamais conceberia qualquer proposta de inquérito. Desta forma ele utiliza todos os argumentos e estratégias da ética comum ao seu alcance, inclusive o açoite com varas, que era um costume romano de aplicar castigos ou de dar

\footnotetext{
${ }^{42}$ BLINZLER, J., Der Prozess Jesu, p. 229-230.

${ }^{43}$ LÉON-DUFOUR, X., Leitura do Evangelho segundo João, p. 76.
} 
lições de moral aos acusados, ${ }^{44}$ na tentativa de dissuadir os acusadores do seu intento funesto.

Konings afirma que, historicamente, Jesus foi morto e crucificado com base na legislação romana, por "razão de Estado" (subversão), e a implicação das autoridades judaicas teve pouco peso. ${ }^{45}$ Infelizmente, essa afirmação não encontra respaldo histórico, textual e mesmo antropológico. Historicamente os judeus também crucificavam e, para tanto havia a maldição correspondente a esse crime (Dt 21,22-23). Ora, existindo a lei, existe a prática. Jesus não é condenado pela jurisprudência romana, mas pela inveja e ignomínia judaica. ${ }^{46}$

\subsection{Eis o vosso rei (Jo 19,14): saem os romanos e entram os judeus}

Desse momento em diante, quem toma a dianteira são os hypêretai (guardas) dos sumos sacerdotes e chefes do povo, não os soldados romanos. Foram os capangas dos sumos sacerdotes que foram, ao Getsêmani, guiados pelo traidor Judas, para apanhar Jesus numa emboscada e executá-lo sem processo jurídico. Nicodemos interferiu no alvoroço provocado pelo sinédrio contra Jesus pedindo que fosse feita uma investigação antes da acusação sumária (Jo 7,51).

$\mathrm{O}$ açoitamento não foi suficiente para os sumos sacerdotes e os chefes do povo desistirem da pena capital. Assim, lavando as suas mãos e descompromissando-se dos fatos, entregou o homem e eles ${ }^{47}$ tomaram Jesus (Jo 19,16). Do Cedron a Pilatos e de Pilatos ao calvário entram em ação os capangas dos sumos sacerdotes. A narrativa de Marcos 15,39, que coloca a presença de um centurião romano, se deve às preocupações que Pilatos tomou para que não houvesse um confronto entre os escarnecedores dos sumos sacerdotes e os discípulos e simpatizantes de Jesus.

\subsection{A maldição da lei: a crucifixão}

Jesus é transformado, religiosamente, num proscrito da lei judaica. Paulo, na carta aos Gálatas, afirma que Cristo nos resgatou da maldição da lei, tornando-se, por nós, em [objeto de] maldição, porque está escrito: "maldito

\footnotetext{
${ }^{44}$ SPEIDEL, K. A., A sentença de Pilatos, p. 112.

${ }^{45}$ KONINGS, J., Evangelho segundo João, p. 328.

${ }^{46}$ GARCÍA-MARTÍNEZ, F., Alguns textos paulinos à luz de Qumram, p. 18.

${ }^{47}$ Aqui são eles, isto é, os soldados dos sumos sacerdotes e dos fariseus. "Eles tomaram Jesus" $(19,16)$. O verbo lambanô, nesse contexto, tem uma conotação de violência, força e imposição, BAUER, W., Lambanô, p. 918.
} 
todo aquele que for colocado num madeiro" (Gl 3,3). Paulo prova o seu ponto de vista com a citação do Deuteronômio: "maldito o que for colocado num madeiro".

Se alguém houver pecado, passível da pena de morte, é morto e pendurado num madeiro, o seu cadáver não permanecerá no madeiro durante a noite, mas, certamente, o enterrarás no mesmo dia; porquanto o que for pendurado no madeiro é maldito de Deus; assim, não contaminarás a terra que IAHWEH, teu Deus, te dará em herança (Dt 21,22-23).

O texto bíblico, como se pode comprovar pelos comentários, éinterpretado, geralmente, no sentido da tradução grega dos LXX, onde está mais claro que no TM, se trata da exposição de um executado ao opróbio, ao ser colocado num madeiro e não tem nada a ver com a crucifixão. Disto, a crucifixão não figura entre os quatro modos tradicionais usados no judaísmo executar a pena capital (apedrejando, queimando, decapitando e estrangulando), e pensava-se, geralmente, que a crucifixão era uma punição característica, muito em voga entre os romanos, porém, totalmente alheia ao mundo judaico. A referência paulina resultava incompreensível, até que um fragmento do Rolo do Templo (1Q19) veio comprovar que o texto do Deuteronômio tinha sido interpretado, em determinadas correntes judaicas, com uma alusão à crucifixão, e outro texto qumrânico, o pesher de Naum, provou, sem dúvida alguma, que a crucifixão era praticada em ambiente judaico, muito antes da chegada dos romanos. ${ }^{48}$

\subsection{Pilatos lava as mãos e manda escrever na cruz a causa mortis}

A expressão lavar as mãos como Pilatos ficou cunhada na história como um ato de covardia. Lendo os relatos da paixão, especialmente o evangelho segundo João, percebemos que há um mal-entendido. Pilatos não lava as mãos no começo do processo, nem manifesta medo diante da cólera dos judeus contra Jesus. Ele recorre a todas as táticas ao seu alcance para libertar o inocente.

${ }^{48}$ GARCÍA-MARTÍNEZ, F., Alguns textos paulinos à luz de Qumram, p. 18. Florentino, que é um grande especialista em Qumram, com diversas obras traduzidas diretamente dos manuscritos de Qumram, faz um comentário sólido sobre a prática judaica da crucifixão. Nesse sentido, quando Pilatos diz aos chefes dos sacerdotes: Eis o vosso rei, eles o conduzem ao patíbulo por conta própria, sem a intervenção do poder romano. Daquele momento em diante, eles assumem a responsabilidade, tal como na narrativa de Mt 27,25: Que o seu sangue caia sobre nós e nossos filhos. 
Pilatos lava as mãos diante da irredutibilidade dos judeus de quererem a pena capital para um inocente. A crucifixão é exigida pelos judeus e não por Pilatos. ${ }^{49}$ A entrevista, a flagelação e a declaração de inocência não bastaram para satisfazer a sede de sangue dos acusadores. Eles ainda usam um argumento paradoxal às próprias convicções: se dizem amigos de César $(19,12)$, ameaçando Pilatos de infidelidade ao Imperador. ${ }^{50}$

Pilatos não quer tirar o corpo fora, como afirma Konings. ${ }^{51}$ Ainda que os judeus tivessem poderes limitados para matar, quando provocados, matavam e, depois, discutiam se era lícito ou não matar (At 7,51-60). No processo de Jesus, eles queriam uma morte mais ignominiosa e que causasse escândalo e espanto para todos os seus seguidores, a fim de que se cumprisse a profecia: morto o pastor, o rebanho se dispersa (Zc 13,7; Mc 14,27).

$\mathrm{O}$ texto joanino pode ter um substrato da vida e das experiências dos cristãos com as sinagogas judaicas nas comunidades paulinas e, de modo especial, na experiência dos cristãos nos acontecimentos imediatos pósressurreição (At 8,1-3), mas não se pode imputar a Pilatos um ato de covardia. ${ }^{52}$ Diante da fúria da multidão agitada e coagida pelos chefes do povo, Pilatos temia por consequências maiores. Diante da resistência de Pilatos em condenar Jesus, os judeus mudaram de foco: em lugar de argumentar pela própria lei que lhes permitia exterminar um blasfemador (como era a acusação a Jesus, 19,7), eles colocaram Pilatos diante de César e, de maneira hipócrita, diziam que só tinham um rei, que era César $(19,15)$. A fim de obter o intento, preferem aclamar o maior inimigo que era o rei de Roma, para pedir o sangue do justo.

Rei dos judeus e não rei de Roma. A reação dos judeus contra Pilatos, uma vez que este, desiludido nas suas tentativas de libertar o inocente, mandou escrever a placa a respeito das motivações que exigiram a sua condenação. A pergunta de Pilatos a Jesus tem um horizonte mais profundo: Tu és o rei dos

\footnotetext{
${ }^{49}$ BOISMARD, M.-É.; LAMOUILLE, A., L'Évangile de Jean, p. 419.

${ }^{50}$ LAMPE, G. W. H., The trial of Jesus the Acta Pilati, p. 174. Segundo o autor, Pilatos teria elaborado uma ata oficial a respeito dos fatos e a enviado ao imperador romano Tibério. Esse documento foi comentado por Justino, mais tarde, considerando-o um documento oficial. Tibério, a partir da ata de Pilatos, teria sugerido incluir Jesus entre as divindades romanas, mas o senado rejeitou a proposta.

${ }^{51}$ KONINGS, J., Evangelho segundo João, p. 328.

${ }^{52}$ COUSIN, H., O profeta assassinado, p. 48. O autor discute a historicidade e a distância entre a época dos fatos e a da redação dos evangelhos. Essa prudência é sempre importante para preservar a historicidade e a lisura hermenêutica, mas também não se pode sustentar a tese de que só há teologia nas narrativas.
} 
judeus (Jo 18,33)? E a resposta de Jesus não se situa na mesma plataforma da pergunta: Meu reino não é deste mundo. Se fosse deste mundo, meus súditos teriam combatido para que eu não fosse entregue aos judeus. Meu reino não é daqui (Jo 18,36).

A pergunta de Pilatos investiga as possíveis relações da ambição de Jesus: ser rei de Israel. A resposta de Jesus, no entanto, vai para outra direção: meu reino não está em organização militar, conquista de territórios ou coisas do gênero.

Pilatos diz a Jesus: Teu povo e os chefes dos sacerdotes entregaramte a mim $(18,35)$. A acusação, portanto, não parte da investigação do poder romano, mas dos líderes religiosos do seu povo. Em todo o processo acusatório, estabelece-se um conflito religioso, mais que jurídico: de um lado estão a inveja, o ódio e a raiva exacerbados e irracionais; do outro, está um pagão, racionalista, que tenta usar o Código de Direito Civil para abrandar uma acusação religiosa.

Como afirma Konings:

a. Ao olhar profano de Pilatos, Jesus é um homem inócuo; ${ }^{53}$

b. Ao olhar dos teólogos (chefes dos sacerdotes), Jesus tem pretensões divinas e por isso deve morrer;

c. Ao olhar dos doentes, mulheres e crianças ele é a misericórdia e libertação;

d. Ao olhar dos falsos puritanos do templo, ele é um traidor dos costumes do passado.

Eis o vosso rei $(19,14)$

Não é o nosso, mas o vosso rei! Isso indica uma separação de cumplicidade. Jesus não está ofuscando a governança de Pilatos e, menos ainda, o poder de César, mas a autoridade do Templo. É o próprio Rolo do Templo que traz a referência da maldição e da aplicação da pena máxima a quem deve ser punido com a execração mais ignominiosa. ${ }^{54}$

\footnotetext{
${ }^{53}$ KONINGS, J., Evangelho segundo João, p. 332.

${ }^{54}$ GARCÍA-MARTÍNEZ, F., Alguns textos paulinos à luz de Qumram, p. 19-21. Esse estudo modifica a compreensão de todo o processo da paixão na tradição cristã.
} 
Pilatos segue um costume romano de colocar em público a causa da morte. Ele não mandou escrever que Jesus era o rei de Roma, mas o rei dos Judeus. Jesus não se fez filho de César ou de alguma divindade romana, mas filho de Deus. Essa declaração ecoava como uma afronta aos princípios e tradições judaicas, mas não afrontava em qualquer aspecto aos costumes romanos. A inocência do condenado e a falácia dos acusadores só encontrou eco no absurdo, como escrevia Rui Barbosa. ${ }^{55}$

\section{Conclusão}

Sendo a crucifixão uma prática judaica, anterior à chegada dos romanos na Palestina, ${ }^{56}$ depois que Pilatos diz: Eis o vosso rei $(19,14)$, Jesus volta às mãos daqueles que o prenderam no Getsêmani. Eles respondem a Pilatos: Nós temos uma lei $(19,7)$, e daqui em diante, assumem o comando dos fatos. Diante disso, é mister analisar o processo de Jesus sob a perspectiva histórica através das narrativas de outros textos da própria tradição judaica. Esses configuram maior historicidade aos próprios evangelhos.

A encenação tradicional da Paixão de Jesus colocando os soldados romanos juntamente com Judas no Cedron e depois na caminhada para o Calvário não corresponde à tradição e narrativas dos evangelhos. No processo de Jesus, é preciso entender três coisas: a. todas as investidas contra Jesus durante a sua missão são movidas pelos chefes religiosos e políticos de Jerusalém e não pelos romanos; b. quem suborna Judas, a fim de que tudo corra na calada da noite, sem conhecimento do povo para prender Jesus, são os chefes dos judeus e não os romanos; c. Judas não recebe de Pilatos as trinta moedas, mas dos anciãos (13,26-30).

Nos aspectos hermenêuticos, vale uma grande reflexão sobre os perigos dos fanatismos puritanos de muitos líderes religiosos. Nesse casso específico do processo de Jesus, um pagão como Pilatos tem mais ética e bom-senso que um grupo de fanáticos deístas judaicos.

\footnotetext{
${ }^{55}$ BARBOSA, R., Obras Seletas de Rui Barbosa, p. 69: "Mas Herodes também não encontra, por onde condenar a Jesus, e o mártir volta sem sentença de Herodes a Pilatos que reitera ao povo o testemunho da intemerata pureza do justo. Era a terceira vez que a magistratura romana a proclamava. Nullam causam inveni in homine isto ex his, in quibus eum accusatis. O clamor da turba recrudesce".

${ }^{56}$ GARCÍA-MARTÍNEZ, F., Alguns textos paulinos à luz de Qumram, p. 20.
} 
Uma religião sem compaixão e sem amor é uma ideologia. Os ritos podem ser perfeitos, mas as mãos podem estar sujas de sangue inocente (Is $1,10-17)$.

\section{Referências bibliográficas}

BAMMEL, E. The poor and the Zealots. In: BAMMEL, E. MOUE, C. F. D. Jesus and the Politics of His Day. Cambridge: University Press, 1992.

BARBOSA, R. Obras Seletas de Rui Barbosa. Rio de Janeiro: A Imprensa, 1899. v. VIII.

BASTIN, M. Jésus devant sa passion. Paris: Cerf, 1976. (Lectio Divina, 92). BAUER, W. Speira. In: BAUER, W. Wörterbuch zum Neuen Testament. Berlin / New York: Walter de Gruyter, 1971. p. 1507.

BAUER, W. Lambanô. In: BAUER, W. Wörterbuch zum Neuen Testament. Berlin / New York: Walter de Gruyter, 1971. p. 918.

BIBLEWORKS 9.0. Norfolk: BibleWorks, 2011.

BLINZLER, J. Der Prozess Jesu. Regensburg: Verlag Friedrich Pustet, 1969. BOISMARD, M.-É.; LAMOUILLE, A. L'Évangile de Jean. Paris: Cerf, 1977. t.III. (Synopse des Quatre Évangiles en Français).

BORING, M. E. Introdução ao Novo Testamento. São Paulo: Paulus; São Bernardo do Campo: Academia Cristã, 2016. v.1 (Questões introdutórias do Novo Testamento e escritos paulinos).

CHAMPLIN, R. N. Lucas; João. In: CHAMPLIN, R. N. O Novo Testamento Interpretado: versículo por versículo. São Paulo: Milenium Distribuidora Cultural Ltda, 1980. v.II.

COUSIN, H. O profeta assassinado: História dos textos evangélicos da Paixão. São Paulo: Paulinas, 1978.

DESROCHE, H. Dicionário de Messianismos e Milenarismos. São Bernardo do Campo: Metodista, 2000.

FERRARO, G. L'Ora di Cristo nel Quarto Vangelo. Roma: Herder, 1974. GARCÍA-MARTÍNEZ, F. Alguns textos paulinos à luz de Qumram. Atualidade Teológica, v.13, n.3, p. 11-32, jan./abr. 2009. 
Guevara, H. Ambiente Político del Pueblo Judio en tiempos de Jesus. Madrid: Cristiandad, 1985.

HENGEL, M. The Zelots: Investigation into the Jewish Freedom Movement in the Period from Herod I until 70 A. D. Edinburg: T\&T Clark, 1989.

JOSEPHUS. The New Complete Works of Josephus. Grand Rapids: Kregel, 1999.

KONINGS, J. Evangelho segundo João: Amor e Fidelidade. São Paulo: Loyola, 2005.

LAMPE, G. W. H. The trial of Jesus in the Acta Pilati. In: BAMMEL, E.; MOULE, C. F. D. Jesus and the Politics of His Day. Cambridge: University Press, 1992. p. 173-182.

LÉON-DUFOUR, X. Leitura do Evangelho segundo João. São Paulo: Loyola, 1998. v.IV.

MAGgIONI, B. Os relatos evangélicos da Paixão. São Paulo: Paulinas, 2000 .

MAZZAROLO, I. João Batista e Jesus conheceram os essênios? In: GASDA, É. E. (Org.). Sobre a Palavra de Deus: Hermenêutica bíblica e teologia fundamental. Petrópolis: Vozes; Goiânia: PUC-GO, 2012. p. 117-132.

MAZZAROLO, I. Nem aqui, nem em Jerusalém: Evangelho de João. Rio de Janeiro: Mazzarolo editor, 2015.

MOLONEY, F. J. The Gospel of John. Collegeville: Daniel J. Harrington Editor, 1998. v.4. (Sacra Pagina Series).

MORGAN, D. F. Between Text \& Community: The "Writigns". In: Canonical Interpretation. Mineapolis: Fortress Press, 1994.

NESTLE-ALAND. Novum Testamentum Graece. 28 ${ }^{\mathrm{a}}$ reimp. Stuttgart: Deutsche Bibelgesellschaft, 2012.

PAGANINI, S. Gesù, Qumran e gli esseni. Milano: Paoline, 2013.

SCHONFIELD, H. J. The Passover Plot. San Francisco: Disinformation Company, 1965.

SPEIDEL, K. A. A sentença de Pilatos: para você entender a paixão de Jesus. São Paulo: Paulinas, 1982.

STUMPFF, A. Zêlos, zêlôtês. In: KITTEL, G. Theological Dictionary of the 
New Testament. Stuttgart: W. Kohlhammer Verlag, 2006. p. 884-888. t.II.

SWEET, J. P. M. The Zealots and Jesus. In: BAMMEL, E.; MOULE, C. F. D. Jesus and the Politics of His Day. Cambridge: University Press, 1992. p. $1-10$.

VAWTER, B. Evangelio según san Juan. In: BROWN, R. E.; FITZMYER, J. A.; MURPHY, R. E. Comentario Biblico "San Jeronimo". Madrid: Ed. Cristiandad, 1972. p. 399-592. t.IV.

YADIN, Y. Bar-Kokhba: The rediscovery of the legendar hero of the Second Jewish Revolt against Rome. New York: Random House, 1971.

Isidoro Mazzarolo Doutor em exegese pela École Biblique et Archéologique Française de Jerusalém Docente da Pontifícia Universidade Católica de Porto Alegre Porto Alegre / RS - Brasil E-mail: mazzarolo.isidoro@gmail.com

Recebido em: 09/10/18

Aprovado em: 20/04/19 